Piotr Krakowiak*

ORCID: 0000-0002-0500-4954

Torun, Poland

\title{
The Loneliness \\ of Home Care Family Caregivers in Poland. Inspirations from Carers UK regarding Social Education for their Inclusion and Support
}

\begin{abstract}
Osamotnienie opiekunów rodzinnych osób ciężko chorych w domach w Polsce. Inspiracje z działań Fundacji Carers UK do edukacji społecznej na temat inkluzji i wsparcia opiekunów
\end{abstract}

\begin{abstract}
Over the last 40 years in Poland, we have been able to change attitudes towards patients with cancer and their family carers. We have learnt from the worldwide hospice movement, and have created our own strategies to provide effective social education for end-of-life care. The nationwide project, Hospicjum to te $\dot{z}$ zycie (Hospice is also life), has helped our hospice-palliative care, but also improved the social acceptance of end-of-life care and support for families of cancer patients in Poland. However, the situation of many elderly and house-bound people, espe-

* Dr. hab. Piotr Krakowiak, Associate Professor, Faculty of Philosophy and Social Sciences, Institute of Educational Sciences, Nicolaus Copernicus University in Toruń, email: pkrakow@umk.pl.
\end{abstract}


cially for patients with dementia and their families, is still very different in Poland. Most families still feel ashamed of being the family with 'mental problems', often isolating themselves from others. Most of our local communities do not support those who suffer and those who care for them, often for many years, in their homes. Social educators and social workers have to address this issue of the loneliness and isolation of many family caregivers: How can one handle feelings of guilt, isolation and loneliness, when one is a family caregiver for someone seriously ill at home? We can gain useful advice from the experience of the British organisation Carers UK. Given that there are already good experiences with cancer patients and their families within the hospice movement in Poland, we can prepare our community leaders, social workers and local communities, to help those other 'lonely heroes' of caring at home to feel more included and supported by us. We can learn from those who have already developed tools and created strategies for supporting family caregivers. Exploring the educational strategies of the successful organisation Carers UK (www. carersuk.org) will help to indicate the main solutions to this social and educational challenge in Poland, thus helping to reduce the loneliness of family carers, especially in home care.

Keywords: palliative and end-of-life care; home care; family carer; loneliness; isolation; support; inclusion.

Streszczenie: $\mathrm{W}$ ciągu ostatnich czterdziestu lat w Polsce byliśmy w stanie zmienić podejście do pacjentów z chorobą nowotworową i ich opiekunów rodzinnych. Od światowego ruchu hospicyjnego nauczyliśmy się opieki, tworząc własne strategie edukacji społecznej w zakresie opieki nad osobami u kresu życia. Ogólnopolski projekt: Hospicjum to też życie pomógł opiece paliatywno-hospicyjnej, poprawiając także społeczną akceptację opieki u kresu życia oraz wsparcie dla rodzin osób chorych na raka w Polsce. Sytuacja wielu osób starszych, uwięzionych w domach, szczególnie w przypadku pacjentów z demencją i ich rodzin, jest w Polsce ciągle zupełnie inna. Większość rodzin wciąż wstydzi się bycia rodziną $\mathrm{z}$,problemami psychicznymi", często izolując się od innych wokoło. Większość naszych lokalnych społeczności nie wspiera tych, którzy cierpią w domach, i tych, którzy się nimi zajmują, opiekując się nimi często przez wiele lat. Pedagodzy społeczni i pracownicy socjalni muszą odpowiedzieć na pytania dotyczące samotności i izolacji wielu opiekunów rodzinnych: jak radzić sobie z poczuciem winy, izolacji i samotności, gdy jesteś opiekunem rodzinnym dla osoby poważnie chorej w domu? Wiele praktycznych porad można zaczerpnąć z doświadczeń brytyjskiej organizacji Carers UK. Po dobrych doświadczeniach zmian w opiece nad pacjentami z chorobą nowotworową i ich rodzinami w ruchu hospicyjnym w Polsce, możemy przygotować liderów 
społeczności lokalnych i pracowników socjalnych do pomocy licznym „samotnym bohaterom" opieki nad chorymi w domu, aby czuli się bardziej włączani i wspierani przez nas. Możemy nauczyć się wiele od tych, którzy już opracowali narzędzia i całe strategie wspierające opiekunów rodzinnych. Badanie elementów edukacyjnych działań odnoszącej sukcesy organizacji Carers UK (www.carersuk.org) pomoże wskazać główne rozwiązania tego wyzwania społeczno-edukacyjnego w Polsce, wspomagając podejmowane już w tym zakresie działania, mające na celu zmniejszenie osamotnienia opiekunów rodzinnych osób u kresu życia w naszym kraju.

Słowa kluczowe: opieka paliatywna; opieka domowa; opiekun rodzinny; samotność; izolacja; wsparcie; inkluzja.

\section{Introduction - a short history of the development and success of the hospice movement in Poland}

From the 1970s onwards, the Hospice Movement in Poland continued the informal activities of a group of enthusiasts, inspired by the Polish Nurse Hanna Chrzanowska. It was supported in 1978 by visits of Dr Cicely Saunders, resulting in the creation of St. Lazarus Hospice in Cracow in 1981 (Krakowiak, 2015a, p. 33). From 1983, the Gdansk home care model developed there and in other places, based on the accommodation available within the Church structures, and on the voluntary work of doctors, nurses and others (Krakowiak, 2008). In 1987, a pain clinic and a palliative-care service were started within the oncology department of the Transfiguration of Jesus Hospital, Poznań (Luczak \& Hunter, 2000). With the democratic changes in Poland, there were more than 100 home care hospices; these emerged from the voluntary work of medics, chaplains and other volunteers, strictly cooperating with family carers (Krakowiak, 2015a). However, with the development of hospice-palliative care, the professionalisation of the service, in line with the requirements of service providers, gave rise to tensions between the grassroots hospice movement based on voluntary service, family caregivers, and professionals. Dialogue helped to resolve some differences and allowed the continued development of the care of terminal patients and their relatives, but 'professional' remained more important than 'integrated' or 'patient and family-oriented' care in Polish hospices (Krakowiak, 2012b). The social education of the general public played an important role in this process.

A new way of discussing end-of-life care was proposed in the 21 st century; the promotion of volunteering was an integral part of it. An innovative 
programme began in Gdańsk, to reintegrate prisoners into society through voluntary work with hospice patients (Krakowiak, Deka \& Janowicz, 2018). The Hospice Foundation had prepared the first nationwide educational campaign, Hospice is also life; and integrated care, volunteering and community involvement to help patients and families had started to gain popularity again. By collaborating with hospices from all over Poland, and assisted by mass-media discussions regarding end-of-life care, family carers and volunteering have made an impact on social education, and have changed attitudes towards family caregivers in hospice-palliative care. In helping families of hospice patients, we are also helping many others, who are still very lonely and struggle to care for elderly and long-term patients at home (Krakowiak, 2012a).

Learning from others has helped us over the years to develop good endof-life care in Poland. Similarly, we want to learn from those who have developed efficient systems of support for family caregivers, in order to implement it and support it with research and educational resources for social work. In order to understand this process, best practice from the UK will be described here briefly, and then the few first steps in Poland towards helping family carers will be presented. During the whole process, social education will be highlighted as the effective way to bring changes in the community. Finally, the conclusion will show what needs to be done in order to help family caregivers feel less lonely in our society.

\section{Carers UK - milestones in a long battle for family caregivers' rights and support}

In 1954 in England, at the age of 31, pastor Mary Webster quit a fulltime job to take care of her ageing and ill parents, as a family caregiver. Ten years later she wrote a letter to a local newspaper about the difficulties of home caring. Her shared story about the difficult experiences of women carers, struggling financially but also with social isolation, made the first important impact. Further articles then appeared with similar emotional messages, which helped to build social awareness in relation to family carers, focused exclusively on women. In 1965, an organization known as the National Council for the Single Woman and Her Dependents was founded, and the first survey regarding caring at home was conducted. As a consequence of these actions, 1967 saw the first-ever legal rights for carers - the Dependent Relative Tax Allowance - introduced by the British government. Later, 
in 1976, the next milestone in supporting family caregivers was the introduction of the Invalid Care Allowance as the first benefit for carers (only for unmarried people) (Carers UK).

In 1981, Judith Oliver founded the Association of Carers, which worked for the extension of the Invalid Care Allowance to married women; this was achieved in 1986, following the victory in the European Court by Jackie Drake, a married carer for her mother. Jackie's case was sponsored by a steering group of more than 50 organisations from the UK. In 1988, Cherrill Hicks, in her book Who cares. Looking after people at home, wrote about a growing number of family carers, thus expanding the social knowledge about informal care, and providing an important tool for social education (Hicks, 1988). Another book worth noting was Carers: research and practice by Julia Twigg, published in 1992. This book showed the scale of the changes, with the author saying that 10 years ago her book could not have been written, and 20 years ago no one would have even considered family caregivers as a subject of research (Twigg, 1992). Years had passed, research had been presented, and in 1995 the Carers National Association, with the support of Baroness Jill Pitkeathley and Malcolm Wicks MP, secured carers' rights in the Carers (Recognition and Services) Act (UK House of Commons, 1995, pp. 424-426). In 1996, the first-ever legal recognition that carers in the UK have needs in their own right was introduced, making space for the creation of the whole movement of respite care for carers (www.nhs.uk).

The 21 st century brought new challenges, and organisations cooperating for the well-being of caregivers in the UK also required changes. In 2001, the Carers National Association was renamed as a nationwide organization, Carers UK. Additionally, and to respond to the devolution process in the UK, partially independent organisations were also announced, and Carers Scotland, Wales and Northern Ireland were created (Carers UK). Consequently, there were regular press releases, campaigns and provocative questions about carers, in order to identify specific needs for support, areas of research, and for lobbying politicians and communities. The roles of respite care, support groups and social assistance were defined, and strategies for the future were created. As a result of effective lobbying and research, and with new means of social communication and the introduction of Carers' Day, The Carers (Equal Opportunities) Act was passed in 2004. This act recognised the needs of carers beyond their caring responsibilities. For instance, this document secured the right to take time off to deal with emergencies, as well as the right to request flexible working hours, and support from employers and trade unions during caring duties. In The History of the Carers' Movement, Timo- 
thy Cook praised Carers UK for evolving into an open-minded group which effectively cooperated with over 40 other organizations. Its campaigns over the years were based mainly on research studies and public education, focused on radio, local and national newspapers, and later on television and new media. Professional competences in advertising techniques and press release messages were also very important; they reached many recipients in the UK, by using strong titles, evoking emotions and sharing real stories of carers. The most important act was putting real carers at the heart of all of its media and educational activities (Cook, 2007).

In 2008, Carers UK secured pension rights for family caregivers, meaning that for the first time, the state pension system treated a lifetime of caring as being on a par with a lifetime of paid work. Carers won protection against discrimination and harassment at work, after carer Sharon Coleman took her case to the European Court with the support of Carers UK and other organisations. As a consequence of this campaign, the Equality Act was introduced in 2010, giving family and informal carers protections from any form of discrimination for the first time in the British legal system. In 2012, new rights were announced for most carers, including more responsibilities for local councils in the UK to assess and support carers. In the 2013 Caring and Family Finance Inquiry, a definitive study into the financial impact of caring was published; this recognised Carers UK's important contribution to the understanding of the financial needs of this section of British society. In 2014, after initially being left out of new care laws, parents who were carers won new rights under the Care Act. During the period of austerity, in 2015 the Carer's Allowance was protected while many other working-age benefits were frozen (Carers UK). All those milestones and changes would not have been possible without continuous educational efforts, and without the research that has been conducted over these 50 years, as has been briefly presented here.

Concluding this presentation of the milestones in the development of care for the carers, one can say that Carers UK was the first charity organisation to fight for the rights and recognition of family carers since the early 1960s. Today, after over 50 years of activity, it is the largest UK organisation that supports carers, and is also conducting research on the loneliness of carers. In 2017, the media in the UK reported that eight out of ten people caring for loved ones 'have felt lonely or socially isolated', as announced by the carer loneliness research report The World Shrinks (Carers UK). Peer-reviewed research regarding the loneliness of carers is available, with protocols helping policy makers gain a better insight into tackling social isolation 
and loneliness (Landeiro et al, 2017), and with various specific research areas for those who want to deepen their knowledge of the topic. One can find a great deal of information in Research Briefings, which are available as online resources of SCIE - the Social Care Institute for Excellence (www.scie. org.uk). Research briefing no. 39, Preventing loneliness and social isolation: interventions and outcomes deals specifically with issues described in this paper (Windle, Francis \& Coomber, 2011). There are also various resources available online that deal with loneliness and isolation for carers, including the regularly updated 'Tackling loneliness' (carers.org). It is worth following the example of these effective actions, in order to understand and help Polish lonely family carers. Organisations supporting them could learn from their battle for carers' acts and rights, as these will eventually change the carers' quality of life, and give them the support they need. The first steps in support of 'lonely heroes' - family carers in Poland - in their daily battles in home care have been already made; these will be presented below, as important elements of the process of social education and inclusion within the patientand family-centred care model.

\section{Volunteers as first support for family carers in palliative home care in Poland}

The history of volunteering is as ancient as the existence of mankind, but here we will try to briefly present and understand today's meaning of the voluntary sector, and the value of the educational functions of hospice volunteering in Poland. It is rooted in human and Christian formation. The development of a voluntary commitment to the needy has been an urgent social need in Poland, and was also called an opportunity to discover a vocation for Christian and humanistic activities. My study of the texts referring to volunteering in the Catholic Church, as an inspiration for both clergy and laity in Polish society, has been published and will not be discussed in detail here (Krakowiak, 2013, pp. 165-184). When democracy in Eastern Europe arrived after a long fight with communist regimes, the activities of hospice volunteers had already been developing in opposition to the then-existing mentality in Poland, called Homo Sovieticus (Krakowiak, Skrzypińska, Damps-Konstańska \& Jassem, 2016, pp. 600-604). From 1981 onwards, the history of modern end-of-life care in Poland was connected to caring communities of voluntary home-care hospice team members. The problems of dying and death, practically absent from the mass media, were not includ- 
ed in the education of healthcare and social welfare employees at that time. Those groups of volunteers in local communities made use of the already developed concept of hospice care; even under communism, where patients and families in Poland were cared for in home centres run by volunteers (Krakowiak, 2015a, p. 38). In concluding this brief history of the roots of volunteering within the hospice movement in Poland, it is useful to emphasise that even under communism, Polish volunteers created many hospice home-care teams. By 1998, Poland was leading Central and Eastern Europe in including hospice and palliative care in healthcare systems. According to recent data, there are now more than 400 different centres of hospice and palliative care in Poland, most of them involving volunteers (Krakowiak \& Pawłowski, 2018).

When the hospice movement was slowly losing its exceptional character of professionals working together with volunteers, accompanied by considerable involvement of church communities, a new way of promoting hospice volunteering was proposed (Krakowiak et al., 2018). The nationwide educational campaign Hospice is also life became a new educational tool to improve social acceptance of end-of-life care and support for lonely caregivers in home care. The National Chaplain of Hospices proposed social education through cooperation with the media, and promotion of public education about the end of human life. The Hospice Foundation, with volunteers, prepared the first nationwide educational campaign. Voluntary service in Poland grew, and started slowly to gain in popularity again. Educational programmes, interviews and reports were launched on the main TV channel in Poland, as well as in other national and regional mass media. In the course of one month, there were around 1,000 media events regarding hospice-palliative care and end-of-life issues (Krakowiak, 2012a). As a result of the national hospice campaign, all the hospices noticed the following: a breaking of the taboo concerning end-of-life issues in the mass media; the consolidation of hospices and palliative care units in Poland; the promotion of voluntary service for those in need, and for their family caregivers. This tradition of public education about end-of-life issues is repeated every year in November, helping to raise awareness and create foundations for local, compassionate communities. In this way, the idea of a public campaign arose, devoted to voluntary service; as a result of which, hospices throughout Poland have received textbooks for volunteers, and they have started preparing and training voluntary service coordinators (Janowicz, Krakowiak \& Stolarczyk, 2015).

In 2007-2010, the Hospice Foundation introduced a project promoting hospice volunteering called 'I like helping', across over 100 hospices in Poland. The project was aimed at volunteer coordinators, who took part in 
training and specialist meetings, and also provided the opportunity to take advice from experts in volunteering. They improved the quality of volunteering in home care, where they have assisted family caregivers in their difficult duties (Krakowiak \& Pawłowski, 2018, p. 92). Volunteering in Poland today is thus less involved in medical care and more about supporting roles such as providing company for patients and their families (Pawłowski et al., 2019), which helps those lonely carers, especially in home care settings. Apart from the important role of volunteering, there are other urgent needs in the system of end-of-life care, which will be briefly presented as possible ways of assisting lonely carers in home care. Most important among them is the coordination of care, involving medical and social dimensions, with the involvement of volunteers, as well as faith and local communities. Social workers often coordinate end-of-life care in Europe, but not yet in Poland.

\section{Social workers as coordinators and educators of integrated care and support}

Since its origins, social work has always been concerned with the seriously ill, dying and bereaved, which reflects the fact that a human being at the end of life has not only medical needs. Apart from the medical aspects of care, there is an urgent need for psychological and spiritual care, as well as for social care. Social work has been part of the modern interdisciplinary hospice team since the beginning (Krakowiak, 2011, p. 246). It might be surprising to hear that a person with a life-limiting illness spends only about $5 \%$ of their time with nurses, doctors, specialists, and the full range of hospice services. According to end-of-life expert Allan Kellehear, as much as 95\% of their time is spent alone, with family carers, friends, and in the community, rather than being engaged with medical professionals. For most patients, dying is not a medical event. For those facing death in home care, this time alone can breed feelings of isolation and loneliness, worry and despair. Dying is more of a social than a medical event, and thus patients should be cared for by a compassionate community, or through engagement with them, with the help of and by adequately trained social workers (Kellehear, 2005).

Unfortunately, professional competencies, standards and procedures, as well as the training available in Western Europe, might overwhelm both social workers and hospice-palliative care teams in Poland. There is to date no adequate training for social workers dealing with end-of-life issues in Poland. The interdisciplinary teams, especially in home care settings, are aware 
of the importance of social work for patients and their caregivers. It has been especially important since 2008, when social workers were excluded from caring hospice teams, their role being neither compulsory nor paid for by the national healthcare institution, NFZ (Krakowiak, 2012b). With many caring teams always short of financial resources, there is the temptation to reduce social workers, thus precipitating a lack of a social dimension in end-of-life care. Social education and research are needed to support a holistic approach, where both medical and non-medical aspects of care - among them, especially social work - are crucial for the patients and their loved ones; both during the care, and also for those in grief and bereavement (Krakowiak, 2011, p. 248).

Finally, the importance of the need to include social work that supports carers should be recognised, because the tasks of a social worker in endof-life care do not end when the patient dies, but also include the support of families in mourning. A social worker, through emotional, informational or structural help and support, prevents social marginalisation. In an ageing society, in the face of the growing number of dependants, and people who are chronically sick at home and dying, specific steps are needed to improve and integrate care at the end of life; including social work in end-of-life care, which is dominated in Poland by nursing and medical activities. Social workers can effectively implement good practices regarding family carers. Initiatives for integrating medical activities, social assistance, volunteering and religious associations must become a reality as soon as possible, built on the mutual understanding, involvement and cooperation of various groups genuinely concerned about people at the end of life and their loved ones (Krakowiak, 2012b). Adequately trained social workers would help doctors and nurses who feel overwhelmed by the growing number of patients and their needs, which are largely of a social nature; these could be met by local, compassionate communities, as happens in some parts of Europe (Wegleitner, Heimerl \& Kellehear, 2016).

\section{Caregivers in Poland - research and first steps towards reducing their loneliness}

Support for family carers has been developed for many years in hospice-palliative care, and has been recently shared in publications especially prepared for all those who face the burden of caring for adults (Krakowiak, Krzyżanowski \& Modlińska, 2010) and for severely ill children (Binnebe- 
sel et al., 2013). One of the first books to present research regarding the situation of family caregivers in Poland was prepared and edited by Mariola Racław in 2011. Its provocative title, Public caring, private care (Publiczna troska, prywatna opieka), shows the growing problems of lonely family members caring for the seriously ill or elderly in their homes (Racław, 2011). The following years brought textbooks dedicated to family caregivers (Krakowiak, Paczkowska, Sikora \& Janowicz, 2013), parishes and spiritual caregivers (Krakowiak, 2015b, pp. 43-58). Research and scientific books from the educational sciences addressed the growing problem of dementia for social workers and carers (Nowicka, 2015), and also the problems of solitude and loneliness of carers (Krakowiak \& Wasilewska-Ostrowska, 2016). At the same time, sociologists started to publicise changes in life expectancy and ageing of the Polish population. The Polish Government issued the 2014-2020 strategy for elderly and housebound people (Ministerstwo Pracy i Polityki Społecznej, 2014), following European research and the prognosis presented by the Council of Europe (2014). There is also a longer prognosis until 2050, showing how quickly Polish society will age in the future and the necessity for solutions regarding health and social care, as well as adequate support for family carers (Waligórska, Kostrzewa, Potyra \& Rutkowska, 2014). It seems that nobody denies the existing and growing problems, but they form only a part of the recommendations, which provide a few practical initiatives regarding family caregivers in home care.

The first of these were the yearly campaigns by Hospice is also life, as tools of public education; since 2016, they have concentrated on family caregivers in end-of-life care. In this way, we have started a public conversation about the 'lonely heroes' in our society - family caregivers in end-of-life home care. Discussions and actions continued for the next three years, helping to raise awareness of the needs of family carers in Polish society (Fundacja Hospicyjna); this resulted in the social campaign, The family carer-does not have to be alone (Kampania społeczna: Opiekun rodzinny - nie musi być sam). The Hospice Foundation carried out three nationwide campaigns, each of which had the goal of drawing social attention to family members who take care of their loved ones at home on a daily basis. The media have helped to show the burdens associated with care, and the possibility of support at individual, local community and institutional level. Through meetings and information in the media and social media, the problem and its scale have been shown, by describing needs in terms of systemic assistance, and building social support networks for family caregivers at local, regional and national levels (Janowicz, 2019, p. 207). 
The online Guide created by the Hospice Foundation for family carers contains a great deal of practical support, and is a valued tool for many lonely family carers (www.opiekunrodzinny.pl, 2019). Another organisation connected to incontinence issues - the TZMO Foundation - has announced an online educational programme: 'This is a project for family carers whose relatives are chronically ill, disabled and dependent', with a growing number of resources available online (Fundacja Damy Radę). There are other local and regional initiatives for family carers in different regions of Poland, which will not be discussed here in detail. In 2018, for the first time a meeting of experts was organised by the Hospice Foundation and Rzecznik Praw Obywatelskich RP (Ombudsman of the Republic of Poland), the purpose of which was to formulate a definition of a family caregiver. The discussion showed many changes taking place in Polish society and families. The meeting was an attempt to create an adequate definition, but also to establish a single term (among those in operation were 'family guardian', 'informal carer', 'unprofessional/unpaid carer', 'actual caregiver', etc.). This discussion will continue, as there is a lack of an adequate and agreed definition of family and respite care (Janowicz, 2019, p. 210).

There has been a sign of hope, as in 2019 the first-ever Polish Government document was issued that provided descriptions of respite care, and the first (very limited) rights for family caregivers of handicapped and disabled children in home care. The 'Respite Care' edition of 2019 is directed at children and disabled people whose family members or guardians require support; this is given in the form of an ad hoc, temporary break in the provision of care, and improvement of their skills and knowledge in the field of caring for these people (Rzeczpospolita Polska). On 2 April 2019, the Minister of Family, Labour and Social Policy in the Polish Government approved the programme entitled 'Respite Care' (2019 edition), which is implemented as part of the Solidarity Fund for Supporting People with Disabilities (Dolnośląski Urząd Wojewódzki). For the first time in Poland, public money has been assigned and distributed for the respite care of handicapped children's family caregivers.

\section{Conclusion. Education and research regarding support for family caregivers is needed in Poland}

As presented in this article, there are many challenges for researchers and practitioners of health and social care, but also for family caregivers and 
the whole society in Poland. Actions already taken in many European countries, and recommendations from the European Union, have already led to the development of plans to support dependent people and their family carers in our country. We need to develop educational aspects of support for family caregivers, at levels ranging from local to national. Furthermore, research is needed from social and medical sciences. There is still a lack of tools to assess the needs of caregivers and their monitoring; these can be adapted from resources available abroad as Research Briefings (https://www.scie.org.uk/) and others. After public education, which has already started with nationwide campaigns (Fundacja Hospicyjna), more practical publications in the Polish language are needed (Janowicz, 2019). Only through educational reading on the solitude and loneliness of family caregivers will we be able to overcome the shortage of regulations in the Polish care system. This system has so far been unable to describe the levels of carers' involvement, and is not responding to the complex needs of carers. If we compare our present situation in Poland, it looks similar to 1976 in the UK, when the first law for family carers and first funds for respite care were allocated (Carers UK) - given that the first ministerial document regarding respite care in Poland was issued in 2019 (Rzeczpospolita Polska).

In terms of research and public education, the educational sciences, and especially social pedagogy and social work, could play an important role in this process, as was described earlier. The valuable role of volunteers in local communities should continue, but new forms of respite care and assistance are needed. Changes in the structure of families and households will soon lead to the reduced caring potential of families in Poland. We have to agree with this opinion: 'Population ageing will have far-reaching social and economic consequences' (Szymborski et al., 2014, p. 24). In the near future in Poland, the implementation of the role of the family carer may also hinder the so-called singularisation of old age; this is associated with the loneliness of the elderly, and the risk of social exclusion. Attention should also be paid to forecasts that the population of Poland will decrease, mainly in cities. At the same time, average life expectancy will increase, with a growing number of elderly and chronically ill people in their homes. Anna Janowicz states that the system of support and respite care for family members in Poland, especially in home care, should respond to their different needs. Family caregivers should be able to combine different roles, to prepare themselves for caring by accessing information and training, as well as to be allowed the required rest. The development and implementation of support systems, appropriate legal regulations, social education, and raising awareness of the situation of 
caring families, are the main challenges for health and social care systems in Poland. All attempts to mobilise social forces in every possible dimension should be considered as important for reducing the stress and burden of family carers. It seems that it is also necessary to intensify social education about the needs of family caregivers of dependent people at home (Janowicz, 2019, p. 204).

In Poland, we need to study and introduce into our society all good practices which have proven successful in achieving the inclusion of carers and reduction of their solitude and loneliness. Those tools which have been developed by Carers UK for over 50 years could be of vital importance for the policy makers, researchers, and practitioners of health and social care. More studies and practical applications from the educational sciences, especially social pedagogy and social work, should follow this initial paper. In particular, reflecting on the recent Carers UK document, called However caring affects you, Our vision for 2021 (Carers UK), will help to prepare the next steps in unifying our effort to give family carers in Poland a less lonely future.

\section{References}

Binnebesel, J., Bohdan, Z., Krakowiak, P., Krzyżanowski, D., Paczkowska, A. \& Stolarczyk A. (red.) (2012). Przewlekle chore dziecko w domu. Poradnik dla rodziny i opiekunów. Gdańsk: Fundacja Hospicyjna.

Carers UK. www.carersuk.com [accessed 14.11.2019].

Cook, T. (2007). The History of the Carers' Movement. London: Carers UK.

Council of Europe. (2014). Population structure and ageing: https://ec.europa.eu/ eurostat/statistics-explained/index.php/Population_structure_and_ageing [accessed 14.11.2019].

Dolnośląski Urząd Wojewódzki. www.duw.pl/pl/urzad/programy/solidarnosciowy-fundusz/opieka-wytchnieniowa/15539, Opieka-wytchnieniowa-edycja-2019. html [accessed 14.11.2019].

Fundacja Damy Radę. damy-rade.info [accessed 14.11.2019].

Fundacja Hospicyjna. www.opiekunrodzinny.pl [accessed 14.11.2019].

Hicks, C. (1988). Who cares. Looking after people at home. London: Random House. Janowicz, A. (2019). Opiekunowie rodzinni. Wyzwania i możliwości wsparcia. Warszawa: Wydawnictwo CeDeWu.

Janowicz, A., Krakowiak, P. \& Stolarczyk, A. (eds.) (2015). In Solidarity, Hospice-palliative care in Poland. Gdansk: Fundacja Hospicyjna. 
Krakowiak, P. (2008). Dzieje pallotyńskiego hospicjum w Gdańsku. Gdańsk: Fundacja Hospicyjna.

Krakowiak, P. (2011). Praca socjalna w opiece u kresu życia na świecie i możliwości jej rozwoju w Polsce. Piel. Zdr. Publ., 1(3), 245-250.

Krakowiak, P. (2012a). Społeczne i edukacyjnej funkcje opieki paliatywno-hospicyjnej. Badania w działaniu 2002-2010. Gdańsk: Fundacja Hospicyjna.

Krakowiak, P. (2012b). Wolontariat w opiece u kresu życia. Studium socjopedagogiczne. Toruń: Wydawnictwo UMK.

Krakowiak, P. (2013). Edukacyjne funkcje wolontariatu i ich percepcja w nauczaniu Kościoła Katolickiego. Paedagogia Christiana, 2, 165-184.

Krakowiak, P. (2015a). Then and now. In A. Janowicz, P. Krakowiak \& A. Stolarczyk (eds.), In solidarity. Hospice-palliative care in Poland (pp. 22-68). Gdańsk: Fundacja Hospicyjna.

Krakowiak, P. (2015b). Zmiany w opiece duszpasterskiej w Polsce. Edukacyjne inspiracje z opieki paliatywno-hospicyjnej i narzędzia do badania potrzeb duchowych. Warszawskie Studia Pastoralne, 1(26), 43-58.

Krakowiak, P. \& Pawłowski L. (2018). Volunteering in hospice and palliative care in Poland and Eastern Europe. In R. Scott \& S. Howlett (eds.), The Changing Face of Volunteering in Hospice and Palliative Care (pp. 83-95). Oxford: Oxford University Press.

Krakowiak, P. \& Wasilewska-Ostrowska, K. (2016). Loneliness Experienced by Informal Caregivers of the Chronically Ill in their Homes. Proposed solutions and practical recommendations for local communities. Society. Integration. Education. Proceedings of the International Scientific Conference, 3, 357-366. DOI: 10.17770/sie2016vol3.1449.

Krakowiak, P., Deka, R. \& Janowicz A. (2018). Solidarity and compassion - prisoners as hospice volunteers in Poland. Ann Palliat Med, 7 (Suppl 2), 109-117.

Krakowiak, P., Krzyżanowski, D. \& Modlińska, A. (eds.) (2010). Przewlekle chory w domu. Poradnik dla rodzin i opiekunów. Gdańsk: Fundacja Hospicyjna.

Krakowiak, P., Paczkowska, A., Sikora, B. \& Janowicz A. (2013). Sztuka komunikacji z osobami u kresu życia. Poradnik dla profesjonalistów i opiekunów nieformalnych - rodzin i wolontariuszy. Gdańsk: Fundacja Hospicyjna.

Krakowiak, P., Skrzypińska, K., Damps-Konstańska, I. \& Jassem, E. (2016). Walls and Barriers. Polish Achievements and the Challenges of Transformation: Building a Hospice Movement in Poland. J Pain Symptom Manage, 52, 600-604. DOI:10.1016/j.jpainsymman.2016.07.009

Landeiro, F., Barrows, P., Musson, E. N., Gray, A. M. \& Leal, J. (2017). Reducing social isolation and loneliness in older people: a systematic review protocol. BMJ Open, 7, 1-5. DOI:10.1136/bmjopen-2016-013778. 
Luczak, J. \& Hunter, G. P. (2000). Hospice care in eastern Europe. The Lancet, 356, 23. DOI: https://doi.org/10.1016/S0140-6736(00)92009-9

Ministerstwo Pracy i Polityki Społecznej (2014). Dlugofalowa Polityka Senioralna $w$ Polsce na lata 2014-2020 w zarysie. www.mpips.gov.pl/seniorzyaktywne-starzenie/zalozenia-dlugofalowej-polityki-senioralnej-w-polsce-na-lata-2014 2020/ [accessed 14.11.2019].

National Health Service UK. www.nhs.uk/conditions/social-care-and-support-guide/support-and-benefits-for-carers/carer-breaks-and-respite-care/) [accessed 7.11.2019].

Nowicka, A. (2015). Opieka i wsparcie osób z choroba Alzheimera i ich opiekunów rodzinnych w Polsce. Zielona Góra: Oficyna Wydawnicza Uniwersytetu Zielonogórskiego.

Pawłowski, L., Lichodziejewska-Niemierko, M., Pawłowska, I., Leppert, W. \& Mróz, P. (2019). Nationwide survey on volunteers' training in hospice and palliative care in Poland. BMJ Supportive \& Palliative Care, 9(3), e25. DOI:10.1136/bmjspcare-2015-000984.

Racław, M. (ed.) (2011). Publiczna troska, prywatna opieka. Warszawa: Instytut Spraw Publicznych.

Rzeczpospolita Polska. (2019). https://www.gov.pl/web/uw-mazowiecki/opiekawytchnieniowa-nowy-program-dla-opiekunow-osob-niepelnosprawnych [accessed 14.11.2019].

Szymborski, J., Iwińska, K., Przewoźniak, K., Błaszczyk, K., Troszyński, M. \& Szylar, A. (2014). Interdyscyplinarna szkoła promocji zdrowia seniorów. Warszawa: Klub Myśli Społecznej Inicjatywy.

Twigg J. (ed.) (1992). Carers: research and practice. London: Her Majesty's Stationery Office.

UK House of Commons (1995). Carers (Recognition and Services) Bill. Parliamentary Papers.

Waligórska, M., Kostrzewa, Z., Potyra, M. \& Rutkowska, L. (2014). Prognozy ludności na lata 2014-2050. Warszawa: GUS. https://stat.gov.pl/files/gfx/portalinformacyjny/pl/defaultaktualnosci/5469/1/5/1/prognoza_ludnosci_na_lata 2014_-_2050.pdf [accessed 14.11.2019].

Wegleitner, K., Heimerl, K. \& Kellehear, A. (eds.) (2016). Compassionate Communities. Case Studies from Britain and Europe. Abingdon: Routledge.

Windle, K., Francis, J. \& Coomber, C. (2011). SCIE Research briefing 39: Preventing loneliness and social isolation: interventions and outcomes. https://www. scie.org.uk/prevention/connecting/loneliness-social-isolation-research-2011 [accessed 10.01.2020]. 